\author{
Joanna Bochaczek-Trabska \\ Iwona Sterczewska \\ Uniwersytet Humanistyczno-Przyrodniczy \\ im. Jana Dlugosza w Częstochowie \\ Wydziat Humanistyczny \\ bochaczek@gazeta.pl \\ i.sterczewska@ujd.edu.pl
}

\title{
Między ekonomią a ekologią Bezpieczeństwo energetyczne III Rzeczypospolitej
}

Znaczenie bezpieczeństwa energetycznego zaczęło wzrastać w drugiej połowie XX w. Stało się to za sprawą rosnących kosztów ropy naftowej. Państwa arabskie zrzeszone w Organizacji Krajów Eksportujących Ropę Naftową (OPEC) wprowadziły czterokrotną podwyżkę cen tego surowca. Jej następstwem stał się kryzys w latach 1973-1983. Wcześniej większość państw europejskich dysponowała rezerwami własnymi, a surowce importowane były tanie. Tym samym nie traktowano polityki energetycznej jako jednej z gałęzi polityki zagranicznej państwa ani narzędzia wywierania wpływu ${ }^{1}$.

Przemiany spowodowane przez Jesień Ludów 1989 r. doprowadzily do demontażu porządku jałtańskiego, stwarzając tym samym Polsce podwaliny pod konstrukcję nowych struktur bezpieczeństwa narodowego. Samo zagadnienie bezpieczeństwa jest niewątpliwie wielopłaszczyznowe i wieloznaczne. Pierwotnie określano nim stan niezagrożenia, spokoju, pewności, wolności od zagrożeń, strachu lub ataku². Obecnie najczęściej jest kojarzone z poczuciem pewności i wolności od zagrożeń ${ }^{3}$. Warto nadmienić, że nie istnieje także jedna uniwersalna definicja bezpieczeństwa energetycznego. Nie można go również rozpatrywać

1 W. Breński, Wybrane problemy gospodarki globalnej i ich wptyw na bezpieczeństwo międzynarodowe, [w:] Bezpieczeństwo międzynarodowe. Wyzwania i zagrożenia XXI wieku, red. P. Olszewski, T. Kapuśniak, W. Lizak, Radom 2009, s. 430; D. Foremny, Bezpieczeństwo energetyczne, [w:] Bezpieczeństwo państwa. Wybrane problemy, red. K.A. Wojtaszczyk, A. Materska-Sosnowska, Warszawa 2009, s. 214-215.

2 R. Kuźniar, Droga do wolności. Polityka zagraniczna III Rzeczypospolitej, Warszawa 2008, s. 86-87; E. Kochanek, Geopolityka energetyczna wspótczesnych państw, Szczecin 2016, s. 38-39; Z. Nowakowski, Polityka bezpieczeństwa energetycznego Polski. Wpływ europeizacji i globalizacji, Warszawa 2016, s. 25, 45-48.

3 J. Stańczyk, Współczesne pojmowanie bezpieczeństwa, Warszawa 1996, s. 16; J. Zając, Bezpieczeństwo państwa, [w:] Bezpieczeństwo państwa..., s. 17; S. Koziej, Wyzwania transformacyjne bezpieczeństwa Polski, „Bellona” 2010, nr 2, s. 7. 
w oderwaniu od innych aspektów bezpieczeństwa, ponieważ jest ściśle związane z polityką trwałego rozwoju, czynnikami ekonomicznymi, ewolucją rynków energetycznych oraz ze zmianami społeczno-ekonomicznymi w transporcie i technologiach informatycznych. Ogólnie można go zdefiniować jako dostępność energii w każdym czasie, w różnych formach, w wystarczającej ilości, po odpowiedniej cenie $^{4}$.

Problem bezpieczeństwa energetycznego należy rozpatrywać szeroko, przede wszystkim uwzględniając aspekty: polityczny, ekonomiczny oraz ekologiczny. Poprzez ujęcie tych płaszczyzn uzyskuje się w miarę kompletny jego obraz $\mathrm{w}$ odniesieniu do danego państwa ${ }^{5}$. Aspekt polityczny obejmuje kontrakty i umowy międzynarodowe na dostawy surowców energetycznych do kraju oraz dywersyfikacje dostaw energii. Uwarunkowania polityczne ukazują w jakim stopniu państwa oddziaływają na zawirowania $\mathrm{w}$ szeroko rozumianej energetyce. Działania te koncentrują się na opracowywaniu odpowiednich strategii i planów, a także na kontroli przedsiębiorstw funkcjonujących na rynku energetycznym. $\mathrm{Z}$ kolei w ujęciu gospodarczym bezpieczeństwo energetyczne koncentruje się na zrównoważeniu popytu i podaży, a tym samym na pokryciu zapotrzebowania na energię. W ujęciu ekologicznym obejmuje ono oddziaływania energetyki na środowisko naturalne ${ }^{6}$.

Posiadanie zasobów surowców energetycznych umożliwia autonomiczny, niezależny od dostaw zewnętrznych rozwój przemysłu ${ }^{7}$. Polska baza tychże jest zróżnicowana. Do najważniejszych zasobów należą złoża: węgla kamiennego, węgla brunatnego, ropy naftowej, gazu ziemnego. Niektóre z wyżej wymienionych złóż występują w kraju w ilościach wystarczających na zaspokojenie potrzeb, inne trzeba importować z zagranicy. Dzięki lokalnym zasobom energetycznym rozwinął się przemysł wydobywczy: górnictwo i kopalnictwo oraz inne gałęzie gospodarki wykorzystujące surowce mineralne bądź ich półprodukty.

Polska gospodarka nadal opiera się na paliwach stałych, głównie na węglu kamiennym i brunatnym. Złoża węgla kamiennego znajdują się $\mathrm{w}$ trzech regionach: Zagłębiu Dolnośląskim, Zagłębiu Górnośląskim oraz Zagłębiu Lubelskim.

4 Bezpieczeństwo międzynarodowe. Teoria i praktyka, pod red. K. Żukrowskiej, M. Grącik, Warszawa 2006, s. 121; M. Ruszel, Bezpieczeństwo energetyczne Polski. Wymiar teoretyczny i praktyczny, Warszawa 2014, s. 25-29, 41.

5 Bezpieczeństwo energetyczne państwa, red. E. Ura, S. Pieprzny, Rzeszów 2015, s. 45-46.

6 J. Kraciuk, A. Jabłoński, Bezpieczeństwo energetyczne Polski, [w:] Bezpieczeństwo międzynarodowe. Wyzwania ..., s. 411; T. Młynarski, Bezpieczeństwo energetyczne i ochrona klimatu w drugiej dekadzie XXI wieku. Energia - Środowisko - Klimat, Kraków 2017, s. 87-89.

7 R. Włoch, Bezpieczeństwo ekonomiczne państwa, [w:] Bezpieczeństwo państwa ..., s. 95; Makowski A., Kubiak K., Znaczenie kierunku morskiego $w$ dywersyfikacji dostaw gazu ziemnego a bezpieczeństwo surowcowe kraju, [w:] Wspótczesne wyzwania bezpieczeństwa europejskiego, pod red. P. Mickiewicz, K. Kubiak, Pelpin, Warszawa 2004, s. 49; M. Pietraś, Autonomiczność bezpieczeństwa energetycznego $w$ stosunkach międzynarodowych, [w:] Bezpieczeństwo energetyczne we współczesnych stosunkach międzynarodowych. Wyzwania, zagrożenia, perspektywy, red. M. Pietraś, J. Misiągiewicz, Lublin 2017, s. 23-24. 
W minionym stuleciu produkowano z niego ok. $60 \%$ energii elektrycznej. Z kolei najtańszą energię uzyskiwano $\mathrm{z}$ węgla brunatnego ${ }^{8}$. Surowiec ten pozyskiwano z kopalni: Adamów, Turów, Bełchatów, Konin oraz Sieniawa, niewielkiej kopalni o zasięgu lokalnym?.

Krajowe wydobycie gazu ziemnego w XX w. pokrywało ok. 1/3 zapotrzebowania na ten surowiec. Strategiczną spółką, która nadal zaopatruje gospodarkę polską w gaz, jest Polskie Górnictwo Naftowe i Gazownictwo SA ${ }^{10}$. Niedobór tego surowca jest wyrównywany poprzez import, zwłaszcza z Rosji, i w mniejszym stopniu z Azji Środkowo-Wschodniej ${ }^{11}$.

Nabywanie gazu ziemnego i jego transport rurociągami jest tańszy od importu ciekłego gazu ziemnego LNG (skraplanie, regazyfikacja oraz transport głównie specjalnie przystosowanymi tankowcami, tzw. gazowcami) ${ }^{12}$. Liczący całościowo $4196 \mathrm{~km}$ gazociąg Jamalski stał się głównym systemem transportu gazu w Polsce. W sierpniu 1993 r. podpisano „Porozumienie między Rządem Rzeczypospolitej Polskiej a Rządem Federacji Rosyjskiej o budowie systemu gazociągów dla tranzytu gazu rosyjskiego przez terytorium Rzeczypospolitej Polskiej i dostaw gazu do Rzeczypospolitej Polskiej”. W umowie strona rosyjska zapewniła stopniowe zwiększanie wielkości dostaw gazu ziemnego do Polski w ramach budowanego systemu gazociągów tranzytowych do poziomu $14 \mathrm{mld} \mathrm{m}^{3}$ rocznie w $2010 \mathrm{r}$. W 1999 r. zakończono budowę pierwszej nitki gazociągu. W 2003 r. podpisano Protokół Dodatkowy wraz z dwoma załącznikami. $\mathrm{Na}$ terytorium państwa polskiego gazociąg był budowany i oddawany do eksploatacji etapami. Jesienią $1996 \mathrm{r}$. zakończono prace budowlano-montażowe na pierwszym 107-kilometrowym odcinku na trasie Owczary-Lwówek, który umożliwił transport gazu z Rosji przez Polskę do Niemiec. W latach 1997-1999 zrealizowano budowę odcinka o długości ok. $210 \mathrm{~km}$ na trasie Lwówek-Włocławek oraz trzeciego o długości ok. $365 \mathrm{~km}$ na linii Włocławek-Kondratki. We wrześniu 1999 r. Europol Gaz SA zakończył budowę całej pierwszej nitki gazociągu Jamal-Europa na terytorium Polski. Planowana budowa drugiej nitki nie doszła do skutku z powodu uruchomienia prac nad gazociągiem Północnym po dnie Bałtyku $^{13}$.

Całkowite zasoby ropy naftowej w Polsce oszacowano na 23,13 mln ton. Część złóż została wyłączona z eksploatacji ze względu na trudną ich dostępność

8 K. Baca, D. Czerwińska, Tani węgiel? To już mit, „Rzeczpospolita” 2011, nr 22 (8838), s. B2.

9 J. Kraciuk, A. Jabłoński, dz. cyt., s. 412-413.

10 A. Naimski, Analiza wyniku polsko-rosyjskich negocjacji gazowych, „Międzynarodowy Przegląd Polityczny" 2010, nr 2/26, s. 49.

11 Bezpieczeństwo energetyczne. Nowy pomiar świata, pod red. A. Kretkowskiego, D. Szweda, Szczecin 2009, s. 51-57.

12 D. Foremny, dz. cyt., s. 234; J. Ćwiek-Karpowicz, Bezpieczeństwo energetyczne Rosji, t. XII, Warszawa 2018, s. 45-48.

13 Międzynarodowe bezpieczeństwo energetyczne wXXI wieku, pod red. E. Cziomera, Kraków 2008, s. 108-109. 
lub też nieopłacalność wydobycia. Roczne zapotrzebowanie Polski na ropę wynosi ok. $20 \mathrm{mln}$ ton. Eksploatacja krajowa zaspokaja jedynie ok. 5\% popytu. $\mathrm{Z}$ tego powodu pozostała część surowca importowana jest głównie z Federacji Rosyjskiej ${ }^{14}$. Import ten odbywa się głównie drogą lądową za pośrednictwem północnej nitki ropociągu „Przyjaźń”, największego na świecie system rurociągów, łączącego Syberię i Europę Srodkową oraz drogą morską przez Naftoport tj. bazę przeładunku paliw płynnych znajdującą się w gdańskim Porcie Północnym. Naftoport posiada zdolność przeładunkową $34 \mathrm{mln}$ ton w ciągu roku ${ }^{15}$.

Federacja Rosyjska dysponuje największymi zasobami gazu ziemnego i jednymi z największych zasobów ropy naftowej. Jest również największym eksporterem gazu ziemnego. Uplasowała się na drugiej pozycji w świecie pod względem eksportu ropy. Mimo że kraj ten należy do głównych eksporterów nośników energii, w wielu regionach ludność rosyjska jest nadal pozbawiona dostępu do niej. Jeszcze pod koniec XX w. szacowano, że ok. 10 mln mieszkańców Rosji żyje w regionach, które nie są przyłączone do sieci przesyłowej energii elektrycznej, a zapotrzebowanie pokrywają niezależne generatory z silnikami diesla lub benzynowymi ${ }^{16}$.

Większości rosyjskiego gazu jest eksportowana na Zachód. Jako główny dostawca tego surowca do Europy może dyktować jego ceny i używać ich jako narzędzi nacisku na arenie międzynarodowej ${ }^{17}$. Polska jest uzależniona od rosyjskich umów. Dotychczas ponad $70 \%$ gazu i $90 \%$ ropy sprowadza się od naszego wschodniego sąsiada ${ }^{18}$.

Dostawy rosyjskich surowców energetycznych na rynki zagraniczne, w tym na rynek polski, stały się instrumentem Moskwy od chwili przejęcia przez rząd pakietów kontrolnych w spółkach, tj. Gazprom oraz wyeliminowanie konkurencyjnych przedsiębiorstw ${ }^{19}$. Obok monopolu Gazpromu nad rosyjskimi rurociągami gazowymi, Rosja sprawuje również pieczę nad rurociągami naftowymi. Poprzez kontrolę państwową, którą są objęte wszelkie interesy z innymi krajami i firmami, Kreml utrzymuje swój wpływ na ceny eksportowanego gazu, najważniejszego źródła dochodu. W Europie Środkowej kompanie rosyjskie, wykorzystując silną pozycję na rynku, wywierały i nadal wywierają presję, by zakupić lub też przejąć kontrolę nad lokalnymi kompaniami surowcowymi, rafineriami oraz dostawcami nośników energii. Rosja swobodnie stosuje metodę „zakręcania

$\overline{14}$ J. Kraciuk, A. Jabłoński, dz. cyt., s. 411-415; T. Kaźmierczak, Bezpieczeństwo energetyczne - implikacje uzależnienia Polski od importu gazu ziemnego, Warszawa 2008, s. 37. D. Foremny, dz. cyt., s. 234.

16 Tamże, s. 92; G. Ronek, Polityka bezpieczeństwa energetycznego Rosji, [w:] Bezpieczeństwo energetyczne we wspótczesnych stosunkach ..., s. 161, 163-168.

17 J. Białek, A. Oleksiuk, Gospodarka i geopolityka. Dokad zmierza świat?, Warszawa 2009, s. 79; A. Bryc, Rosja w XXI wieku. Gracz światowy czy koniec gry? Warszawa 2009, s. 41-43.

18 Gaz a sprawa polska, „Tygodnik Powszechny” 2009, nr 47 (3150), s. 12; Bezpieczeństwo energetyczne wyzwaniem XXI wieku, red. Z. Lach, Warszawa 2013, s. 37. Bezpieczeństwo energetyczne. Nowy pomiar..., s. 63. 
kurka" wobec poszczególnych państw. Gazprom wykorzystuje wiele instrumentów, aby możliwie jak najbardziej uzależnić strategicznych partnerów od dostaw swojego gazu. Należą do nich m.in.: kontrakty długoterminowe, które pozwalają kreować politykę zagraniczną, a z czym związana jest rozbudowa gazociągów omijających kraje tranzytowe oraz blokowanie alternatywnych dróg przesyłu ${ }^{20}$. Na marginesie można dodać, że rosyjsko-ukraiński kryzys gazowy, który miał miejsce na początku 2009 r. dowiódł, że zintegrowany europejski rynek energii może być również podstawowym narzędziem zapewniającym bezpieczeństwo energetyczne państw członkowskich ${ }^{21}$.

Metoda „zakręcania kurka” była jak dotąd skuteczna, ale w szerokiej perspektywie zmusza ona państwa poddawane presji do szukania innych, pewniejszych dostawców surowców energetycznych. Innym sposobem zwiększenia przez Moskwę kontroli nad dostawami surowców energetycznych jest rozbudowa systemu przesyłowego ropy i gazu. Jednym z elementów rosyjskiej ekspansji w sektorze gazowym jest ciągłe wzmocnienie pozycji Gazpromu na rynku europejskim jako najważniejszego eksportera surowca oraz znaczącego inwestora. Gazprom prolongował kontrakty z największymi stałymi kontrahentami: Niemcami, Włochami, Francją oraz Austrią. Już w 2006 r. wszedł na rynek węgierski, a w 2007 r. podpisano długoterminowy kontrakt $\mathrm{z}$ rumuńską spółką Conef na dostawy gazu w latach 2010-2030. Kontrakt ten zapewnił Gazpromowi dostęp do rumuńskiego rynku wewnętrznego ${ }^{22}$.

Ostatnie dekady pokazały, jak zacieśniała się niemiecko-rosyjska współpraca na płaszczyźnie bezpieczeństwa energetycznego, która ostatecznie doprowadziła do ukształtowania się tzw. partnerstwa strategicznego. Najlepszym przykładem jest porozumienie między tymi krajami w sprawie budowy Gazociągu Północnego (Nord Stream), który z założenia omija tradycyjne kraje tranzytowe, w tym Polskę. Niemcy ze względu na brak samowystarczalności są zmuszone do importowania nośników energii, zwłaszcza gazu i ropy. Jednak polityka energetyczna UE powinna polegać na solidarnym podziale ryzyka z potencjalną

20 Jak Rosjanie wykorzystują „broń gazową” może świadczyć chociażby przypadek Białorusi, gdy skłócony z Aleksandrem Łukaszenką Gazprom postanowił w lutym 2004 r. zakręcić kurek. Konflikt ten odczuła również gospodarka polska. Połowy potrzebnego surowca zostały wówczas pozbawione zakłady azotowe - pięć największych fabryk (Police, Tarnów, Włocławek, Kędzierzyn i Puławy) - kupujące ponad 20\% gazu zużywanego każdego dnia w Polsce. Ponadto ograniczono dostawy dla Petrochemii w Płocku oraz Gdańsku. D. Wybranowski, Bezpieczeństwo Polski w stosunkach z Federacja Rosyjska w 2005 roku - zagrożenia i perspektywy, [w:] Bezpiecznie czy niebezpiecznie? Wybrane aspekty globalnej i polskiej polityki bezpieczeństwa na przetomie XX i XXI wieku, pod red. J.J. Piątka, R. Podgórzańskiej, Szczecin 2007, s. 148; A. Łoskot, Bezpieczeństwo dostaw rosyjskiego gazu do UE - kwestia połaczeń infrastrukturalnych, Warszawa 2005, s. 6.

21 P. Szlagowski, Priorytety polskiej polityki energetycznej w Trzecim Strategicznym Przegladzie Sytuacji Energetycznej, „Międzynarodowy Przegląd Polityczny” 2010, nr 2/26, s. 68.

22 Międzynarodowe bezpieczeństwo energetyczne..., s. 107-108. 
„blokadą energetyczną”, a nie zawieraniu separatystycznych porozumień z Moskwą ${ }^{23}$. Trudno się zatem dziwić, że podpisanie przez kanclerza Gerharda Schroedera $^{24}$ i prezydenta Władimira Putina umowy w sprawie budowy rurociagu zostało odebrane $\mathrm{w}$ Polsce jako przejaw łamania solidarności europejskiej przez Niemcy i wzbudziło historyczne odwołania: „Najpierw toast wznoszono w Moskwie 23 lipca 1939 roku. Teraz przyszedł czas na toast w Berlinie -8 września 2005 roku o godz. 14.30. Sześćdziesiąt sześć lat temu Ribbentrop i Mołotow uzgodnili warunki rozbioru przez Niemcy i Rosję oraz potwierdzili warunki dostaw ropy do Niemiec [...] teraz w berlińskim hotelu Intercontinental dokonano gazowego rozbioru Polski i określono warunki dostaw gazu z Rosji do Niemiec" 25 . Obecna kanclerz Niemiec Angela Merkel stwierdziła wówczas, że Europa potrzebuje rosyjskiego gazu w tym samym stopniu, co Rosja jego odbiorców w Europie ${ }^{26}$.

Jak wspomniano, Gazociąg Północny umożliwia Rosji dywersyfikację kierunków eksportu gazu ziemnego z pominięciem takich państw tranzytowych jak: Ukraina, Białoruś czy Polska, co uwalnia Gazprom od konieczności opłat tranzytowych. Ponadto Rosja nie musi tracić czasu na długotrwałe negocjacje taryfowe z państwami, przez które biegnie gazociąg, ani obawiać się wstrzymania tranzytu. Wynikające z pierwotnego założenia wyeliminowanie przez Gazprom pośredników pozwala na utrzymanie opłacalności projektu. W relacjach bilateralnych z Polską strona rosyjska kilkakrotnie podkreślała, iż Gazociąg Północny służy interesom całej Unii, ponieważ zmniejsza ryzyko zakłóceń dostaw surowca wskutek uwolnienia się od niepewnych krajów tranzytowych - Białorusi i Ukrainy. Realizacja tego projektu stała się dla Polski z oczywistych powodów niekorzystna, gdyż marginalizuje jej rolę w tranzycie rosyjskiego gazu do Europy Zachodniej. Ponadto osłabiła polskie bezpieczeństwo energetyczne - Rosja w każdej może zamknąc dostawy gazu do Polski, nie przerywając jego dopływu do państw zachodnioeuropejskich ${ }^{27}$.

$\mathrm{Na}$ początku 2006 r. rząd polski zaproponował Niemcom ustanowienie „energetycznego NATO” w ramach UE na bazie solidarności między państwami członkowskimi. Niemcy sceptycznie odniosły się do tej propozycji. Swoją decyzję uzasadniły następująco:

23 J. Białek, A. Oleksiuk, $d z$. cyt., s. 81-82; A. Bryc, $d z$. cyt., s. 44; A. Mackiewicz, Gaz a sprawa polska, „Tygodnik Powszechny” 2009, nr 47, s. 12.

24 Gerhard Schroeder po 2005 r. prowadził zarówno w siedzibie konsorcjum Gazociągu Północnego na terenie Szwajcarii, jak również w Niemczech i innych krajach Europy intensywną kampanię promocyjną. Mimo krytyki Gazociągu Północnego w Szwecji, Polsce, Finlandii i krajach bałtyckich, działalność promocyjną na rzecz kontynuacji jego budowy w latach 2005-2007 prowadziły również koncerny niemieckie i zachodnie. Poparcia politycznego udzieliły mu rządy: niemiecki, francuski, holenderski i brytyjski. Międzynarodowe bezpieczeństwo energetyczne..., s. 58-59.

J. Jartyś, Stosunki polsko-niemieckie w aspekcie bezpieczeństwa europejskiego, [w:] Bezpiecznie czy niebezpiecznie?..., s. 120; J. Piński, Pakt Putin-Schroeder, „Wprost” 2005, nr 37, s. 30. 
- istnieje konieczność wyjścia poza ramy Paktu Północnoatlantyckiego przy rozwiązywaniu złożonych kwestii bezpieczeństwa;

- dążenie do osiągnięcia bezpieczeństwa energetycznego wymaga wynegocjowania „Karty Energetycznej” UE-Rosja przy utrzymaniu dialogu energetycznego z Moskwą, mimo złożenia przez Polskę weta przeciwko negocjowaniu nowego traktatu o współpracy UE-Rosja pod koniec 2006 r. (Polska zapowiedziała odejście od weta dopiero w marcu 2008 r. po częściowym zniesieniu przez Rosję embarga na produkty polskie);

- przy kształtowaniu „solidarności energetycznej” w ramach UE istnieje konieczność wypracowania odpowiednich mechanizmów uwzględniających działania w sytuacjach kryzysowych (np. udzielania pomocy w razie wystąpienia niedoborów zaopatrzenia energetycznego w UE, w tym również w odniesieniu do Polski);

- koncepcja ta wymaga współdziałania państw, ale również koncernów energetycznych oraz krajów produkujących i posiadających surowce energetyczne ${ }^{28}$.

Ze względu na ogromny potencjał gospodarczy oraz wzrastające zapotrzebowanie na surowce energetyczne Niemcy oparły swoją strategię bezpieczeństwa na równoległych działaniach ekonomicznych i politycznych w kierunku oszczędzania energii, zmniejszenia zużycia surowców energetycznych, zwiększenia jej produkcji ze źródeł odnawialnych oraz utrzymania poprawnych stosunków politycznych zarówno z krajami produkującymi, jak i kontrolującymi szlaki tranzytowe importowanych nośników energii ${ }^{29}$. Z kolei Polska zajęła stanowisko obrony „,solidarności ekonomicznej”. W projekcie „Polityki energetycznej Polski do 2030 r.", który został przedstawiony we wrześniu 2008 r., podkreślano również, że „bezpieczeństwo energetyczne Polski oparte będzie na własnych zasobach surowców, zwłaszcza węgla" ${ }^{30}$. Oprócz tego do podstawowych kierunków polskiej polityki energetycznej zaliczono wówczas: poprawę efektywności energetycznej, wzrost bezpieczeństwa energetycznego, rozwój wykorzystania odnawialnych źródeł energii (w tym biopaliw), rozwój konkurencyjnych rynków paliw oraz ograniczanie oddziaływania energetyki na środowisko ${ }^{31}$. Wymienione kierunki, jak i dotychczasowy kształt polityki energetycznej Unii Europejskiej, były

\footnotetext{
Tamże, s. $62-63$.

29 Tamże, s. 68.

30 R. Włoch, $d z$. cyt., s. 115.

31 W 2005 r. Unia Europejska wprowadziła na swoim obszarze oparty na zasadach rynkowych System Handlu Uprawnieniami do Emisji Gazów Cieplarnianych (ETS). Każde państwo członkowskie zostało zobowiązane do utworzenia krajowego rejestru uprawnień do emisji, który jest częścią systemy i posiada postać elektronicznej bazy danych. Szerzej zob.: Ekonomiczne instrumenty ochrony środowiska. Emisje pod nadzorem, „Nowe Życie Gospodarcze" 2010, nr 12, s. 24; K. Forowicz, Trudne lata dla polskich przedsiębiorców. Surowe limity darmowych uprawnień CO2, „Nowe Życie Gospodarcze” 2010, nr 12, s. 22; T. Młynarski, $d z$. cyt., s. 89-93.
} 
podstawą dla wskazania priorytetów naszego kraju w ramach polityki europejskiej ${ }^{32}$.

W chwili wstąpienia Polski do Unii Europejskiej sektor energetyki stanął przed nowym wyzwaniem - dostosowaniem się do zasad, które obowiązują podmioty unijne. Już w $1995 \mathrm{r}$. zsynchronizowano polski system elektroenergetyczny $\mathrm{z}$ zachodnioeuropejskim systemem UCTPE (obecnie UCTE - Union for the Coordination of Transmission of Electricity). Realizowany przez Polskę projekt tzw. mostu energetycznego pomiędzy Polską a Litwą stał się wówczas strategicznym projektem naszego kraju w zakresie połączeń elektroenergetycznych w kierunku wschodnim. Stanowi ono istotne ogniwo tzw. „Pierścienia Bałtyckiego” obejmującego systemy elektroenergetyczne krajów nadbałtyckich. W procesie akcesyjnym do UE Litwa wyraziła zgodę na zamknięcie starej elektrowni atomowej w Ignalinie. W 2006 r. premierzy Litwy, Łotwy i Estonii podpisali deklarację o wspólnej budowie „Ignalina II"33.

Priorytetem w zakresie polityki energetycznej RP jest zapewnianie stabilnych i nieprzerwanych dostaw energii na podstawie długoterminowych kontraktów ${ }^{34}$. Jednocześnie należy uwzględnić konieczność zwiększenia konkurencyjności i efektywności gospodarki energetycznej ${ }^{35}$. Podejmowane działania w tym zakresie to fuzja interesów ekonomicznych, bezpieczeństwa narodowego i kwestii ochrony środowiska ${ }^{36}$.

W 2005 r. Ministerstwo Gospodarki przeprowadziło rozmowy na temat możliwości inwestowania w budowę gazociągu z zachodniej Norwegii do Polski. Jednak ze względu na potencjalne koszty oraz konieczność zakontraktowania dużych ilości gazu, których Polskie Górnictwo Naftowe i Gazowe (PGNiG) nie było wówczas w stanie sprzedać, projekt ten nie został zrealizowany. Można sądzić, że byłby on realnym sposobem na dywersyfikację dostaw gazu ziemnego do Polski. Zyskał również wsparcie UE, która w marcu 2005 r. opowiedziała się za rozbudową infrastruktury energetycznej w kierunku północnym. Do realizacji projektu połączenia z Norwegią, a szerzej Skandynawią, przystąpiono natomiast poprzez dołączenie do projektu budowy gazociągu Skandel, łączącego Norwegię z Danią i Baltic Pipe - w celu transportu surowców z Danii do Polski i utworzenia połączenia międzysystemowego. Przedsięwzięcie to określono jako element projektu Bramy Północnej, czyli połączenia złóż gazu znajdujących się na szelfie norweskim $\mathrm{z}$ polskim wybrzeżem. Porozumienie $\mathrm{w}$ tej sprawie podpisano w 2007 r. - przedstawicielem Polski było PGNiG, Duńczyków reprezentowała firma Energinet.dk oraz operator gazociągów przesyłowych Gaz-System. Dwa

\footnotetext{
P. Szlagowski, $d z$. cyt., s. 66.

D. Foremny, dz. cyt., s. 228-229.

J. Gołębiewski, Anatomia bezpieczeństwa, Warszawa 2015, s. 66-68.

35 Szerzej na ten temat: D. Foremny, $d z$. cyt., s. 225-226; B. Mayer, Czas na małe, lokalne źródła energii, „Rzeczpospolita” 2011, nr 22 (8838), s. B11; T. Młynarski, Polityka energetyczna Unii Europejskiej w pierwszej połowie drugiej dekady XXI wieku, [w:] Bezpieczeństwo energetyczne we wspótczesnych stosunkach ..., s. 117.
}

D. Foremny, dz. cyt., s. 226, 235. 
lata później PGNiG podjęło decyzję o przekazaniu inwestycji do Gaz-Systemu. Zgodnie ze swoim oświadczeniem spółka PGNiG planuje rozpocząć korzystanie z gazociagu do 2022 r. i sprowadzać nim kilka miliardów $\mathrm{m}^{3}$ gazu $^{37}$. W $2017 \mathrm{r}$. premier Rzeczypospolitej Polskiej Beata Szydło i premier Danii Lars Lokke Rasmussen podpisali memorandum w sprawie budowy gazociągu. Rok później sygnowano umowę między Polską a Danią dotyczącą budowy gazociągu, a w kwietniu 2019 r. prezydent Andrzej Duda ratyfikował ustawę Parlamentu RP w sprawie budowy gazociągu Baltic Pipe ${ }^{38}$.

Mimo powtarzających się od końca XX w. ostrzeżeń, iż kończą się zasoby węgla, ropy naftowej i minerałów, rynek na swój sposób komunikuje, że podaż surowców nieprzerwanie nadąża za zapotrzebowaniem. Gdyby było inaczej, ceny szybko zaczęłyby się piąć w górę - owszem, tak się dzieje, ale w krótkich okresach. W dalszej perspektywie ceny rynkowe osiągają stabilizację. Co ciekawe, ta prawidłowość stała się przedmiotem najsłynniejszego zakładu w historii ekonomii. Amerykański ekonomista Julian Simon wyzwał na intelektualny pojedynek Paula Ehrlicha, autora „Bomby populacyjnej” z 1968 r. Ostatni z wymienionych $z$ uporem przekonywał, iż świat stoi przed perspektywą rychłego wyczerpania się zasobów, a tym samym przed widmem katastrofy. Z kolei Simon stwierdzil, że z ekonomicznego punktu widzenia nie istnieją tzw. bariery dla rozwoju; pojęcie zasobu nie posiada charakteru obiektywnego, lecz względny, co należy rozumieć, że jest on zależny od stanu ludzkiej wiedzy i poziomu rozwoju technicznego. Te $z$ kolei determinuje ludzka innowacyjnośćc ${ }^{39}$.

Niedobory surowców mogą wynikać z różnych przyczyn: z polityki poszczególnych państw, które mogą zmniejszyć eksport na światowy rynek w celu podwyższenia cen; z niedostatków związanych z sytuacją geologiczną, co wiąże się $\mathrm{z}$ warunkami wydobycia i może prowadzić do wzrostu cen oraz dewastacji środowiska; z wyczerpywania znanych nam pokładów. Gdyby podzielić ilość węgla pod ziemia przez roczne wydobycie, to faktycznie Polska posiada go na ok. 200-300 lat. Z kolei, jeżeli uwzględnimy czynnik ekonomiczny - kryterium opłacalności, to nasze zasoby węgla wystarczą na około $20 \mathrm{lat}^{40}$.

Zwiększenie zapotrzebowania na zasoby surowców energetycznych i pozyskiwaną z nich energię jest spowodowane wzrastającym tempem rozwoju gospodarek światowych. W efekcie państwa biorą kurs na zapewnianie sobie dostępu do surowców energetycznych w takim stopniu, który zagwarantuje im bezpieczeństwo w przypadku przerw w zaopatrzeniu. Stan ten może zapewnić dywersyfikacja dostaw nośników energii, zwiększenie wydobycia krajowego, poszukiwanie i eksploatacja nowych złóż oraz inwestycje w alternatywne źródła energii ${ }^{41}$.

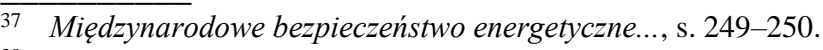

38 Baltic Pipe, https://pl.wikipedia.org/wiki/Baltic_Pip, (dostęp: 19.07.2019).

39 E. Bendyk, Jak nie zginać i zarobić?, „Polityka” 2018, nr 44 (3184), s. 43.

40 D. Karpiuk, Już mamy katastrofe, „Newsweek Polska” 2019, nr 29, s. 22.

41 D. Foremny, dz. cyt., s. 213; Polityka bez strategii. Bezpieczeństwo Europy Środkowo-Wschodniej w perspektywie ładu globalnego, pod red. A.Z. Kamińskiego, Warszawa 2008, s. $126-127$. 
Konsekwentny wzrost wykorzystywania odnawialnych źródeł energii skutkuje większym uniezależnieniem się Polski od dostaw energii z importu, zwłaszcza ropy i gazu. Wiele problemów na szczeblu lokalnym i regionalnym wiąże się $\mathrm{z}$ emisją tlenków azotu. W regionie bałtyckim zakwaszenie gleby i wód są znamiennym tego przykładem ${ }^{42}$.

Wraz z rozwojem nowoczesnych technologii na znaczeniu zyskują coraz to nowe metale i surowce, np. miedź, którą wydobywano od tysiącleci. Jednak szczególnego znaczenia nabrała w momencie wynalezienia elektryczności. $Z$ biegiem czasu odkrywane są coraz nowsze metody pozyskiwania energii, np.: energia wodna, energia geotermalna, energia słoneczna, energia wiatru, biogaz, biomasa (drewno, słoma, odchody zwierząt) ${ }^{43}$.

Nierozerwalne ogniwo bezpieczeństwa energetycznego stanowi ochrona środowiska naturalnego. Mimo licznych inicjatyw obecne formy wykorzystania energii dalekie są od ekologicznie zrównoważonych. Jednym z zagrożeń dla środowiska jest niewątpliwie efekt cieplarniany. Prawie połowa wytwarzanych przez człowieka gazów cieplarnianych pochodzi z sektora energetycznego. Na tę kwestię nakłada się czynnik społeczny. Na granicach Unii widok uchodźców stał się niemal powszechny. Oprócz względów politycznych i ekonomicznych wznoszą postulaty ekologiczne: „zmieniliście klimat tak, że nie możemy mieszkać tam, gdzie nasi przodkowie”"44. Według słów Marcina Popkiewicza: „największy wpływ na globalne ocieplenie ma dwutlenek węgla. Atomy węgla są w wielu miejscach w przyrodzie: w oceanach, w atmosferze, w drzewach, w nas też. Do niedawna ilość atomów węgla w środowisku była względnie stała, krążyła sobie między atmosferą, biosferą i oceanami. Trochę dorzuciły wulkany, ale to za mało. I nagle pojawia się człowiek i stwierdza: paliwa kopalniane są fajne. Można tym napędzać samochody, zasilać elektrownie. Leżały pod ziemią od setek milionów lat [...], a my je w ekologicznym mgnieniu oka wyciągamy spod ziemi. Spalamy węgiel, ropę, gaz i wypuszczamy nowe atomy węgla do środowiska. Robi się nierównowaga. [...] Jedną czwartą tego, co wpuszczamy do atmosfery, pochłaniają oceany, jedna czwartą - ekosystemy lądowe, połowa w atmosferze zostaje" ${ }^{45}$. A jakie są efekty? Po pierwsze niepokojący wzrost temperatury, dalej - zakwaszenie oceanów, które powoli zmieniają się w wodę gazowaną. Zmienia się roślinność, płoną lasy. Dla przykładu, dla rosnących w Polsce świerków zaczyna być za ciepło. Istnieje realne prawdopodobieństwo, że klimat umiarkowany zmieni się nam na śródziemnomorski ${ }^{46}$. Bałtyk powoli przeistacza się w morze martwe, co widać choćby na przykładzie zmniejszającej się populacji ryb. Jak twierdzi dr Zbigniew Karnicki z Morskiego Instytutu Rybackiego w Gdyni: „Na początku lat 80. zeszłego wieku dorsza było bardzo dużo; mówiło się, że po

\footnotetext{
42 R.M. Czarny, M. Tomala, Wymiar pótnocny Unii Europejskiej. Studium rozwoju, Kielce 2009, s. 92.

43 Bezpieczeństwo międzynarodowe. Wyzwania..., s. 430.

44 D. Karpiuk, dz. cyt., s. 19-22.

45 Tamże, s. 20-21.

46 Tamże, s. 22.
} 
grzbietach ryb można by przejść na piechotę do Szwecji. Nie słyszałem, żeby komuś się to udało, ale wiem, że w jeden rok łowiło się wtedy tyle, co teraz w 13 lat" ${ }^{\prime 4}$.

Warto zauważyć, że w minionych 30 latach Europa wydała na naprawę szkód wywołanych ociepleniem klimatu 400 mld euro. Polskie koszty szacuje się na 14 mld euro. Pozostaje pytanie: jakie koszty wygenerują kolejne lata? Województwo łódzkie zaczyna przypominać pustynię, Kujawy stały się obszarem regularnej suszy, coraz częściej słyszymy o osuwiskach w Małopolsce. Z kolei Bałtyk smagany jest sztormami, postępuje erozja wybrzeża. $Z$ jednych regionów naszego kraju donoszą o dokuczliwym niedoborze wody, z innych o powodziach. Do tego dochodzą wielodniowe fale ekstremalnych upałów i gwałtowne wyładowania atmosferyczne, z towarzyszącymi im często trąbami powietrznymi. Wszystko to ma swoje przełożenie na rolnictwo, transport i energetykę. Co gorsza, to nie wyliczanka z broszury radykała, ekologa fanatyka, lecz wykaz z przygotowanego jesienią 2018 r. raportu Ministerstwa Środowiska - „Polityka ekologiczna państwa 2030", dotyczącego skutków ocieplania się klimatu ${ }^{48}$. Według jego autorów zmiany klimatu będą miały znamienny wpływ szczególnie na gospodarkę wodną kraju. „Polska ma stosunkowo niewielkie zasoby wodne, a efektywność ich wykorzystania jest niska. W niektórych regionach już teraz identyfikowane są okresowe problemy $\mathrm{z}$ zaopatrzeniem w wodę. Jednocześnie, we wszystkich częściach kraju wzrośnie ryzyko wystąpienia powodzi, co związane jest z niewystarczającą zdolnością retencyjną naturalnych i sztucznych zbiorników oraz wzrostem udziału powierzchni nieprzepuszczalnych, szczególnie w miastach"49.

Jak wspomniano, poważny problem stanowią krajowe rezerwy wody oraz świadome ekonomiczne jej wykorzystywanie. Polska wysycha. Latem Polacy modlą się o wodę; przez resztę roku robią wszystko, żeby jej się pozbyć. Wysychają studnie, a ujęcia wód podziemnych w miastach i wsiach są na granicy zapotrzebowania. Niedobory wody to problem wielopoziomowy. Pierwszy stanowią warunki klimatyczne i geologia. Polska ma jedne z najniższych odnawialnych zasobów wodnych w przeliczeniu na mieszkańca, co stawia nasz kraj na jednym z przedostatnich miejsc w Unii, jak również za wieloma państwami tzw. strefy suchej, tj.: Sudan, Czad, Niger czy Australia. Kolejny poziom to zmiany klimatyczne. Obserwuje się regularny wzrost miesięcznej i rocznej średniej temperatury powietrza. Dla wyjaśnienia, wraz ze wzrostem temperatury rocznej parowanie terenowe staje się intensywniejsze i większa część opadów powraca do atmosfery zamiast wsiąkać czy też odpływać do wód powierzchniowych. W ten sposób zmiany klimatu uszczuplają odnawialne zasoby wodne ${ }^{50}$. Kolejny aspekt

\footnotetext{
47 J. Ćwieluch, Skóra i ości, „Polityka” 2019, nr 29 (3219), s. 30.

48 R. Omachel, Pieniadze albo życie, „Newsweek Polska” 2019, nr 29, s. 36.

49 S. Bujalski, Nadchodzi katastrofa. Województwo łódzkie zmienia się w pustynię. Raport, http://lodz.wyborcza.pl/lodz/7,44788,24871387,nadchodzi-katastrofa-wojewodztwo-lodzkie-zmienia-sie-w-pustynie.html, (dostęp: 19.07.2019).

50 M. Sepioło, Schnaca Polska, „Polityka” 2019, nr 28, s. 33-34.
} 
stanowi niespójna gospodarka wodna - wodę powinno się retencjonować w miejscach, gdzie dociera ona w postaci opadu, nie zaś, jak w większości przypadków, w zbiornikach retencyjnych położonych setki kilometrów dalej ${ }^{51}$.

Za kolejną przyczynę wysuszania uważa się przemysł oparty na węglu, a konkretnie wydobyciu węgla kamiennego. Na Pojezierzu Gnieźnieńskim, krainie znajdującej się na granicy Wielkopolski i Kujaw, z jeziorem Gopło, efekty widać jak na dłoni. Poziom jeziora się obniża, a do wody trafiają szkodliwe substancje chemiczne. W lasach tego regionu drogi są kręte, a piasek głęboki i sypki; pnie drzew przy drodze przybierają powoli żólty kolor $^{52}$.

Mimo ponurych prognoz na szczycie w Brukseli, w czerwcu 2019 r., premier Mateusz Morawiecki wraz z przedstawicielami Czech, Estonii i Węgier, nie wyrazili zgody na wpisanie do końcowych ustaleń radykalnej redukcji emisji dwutlenku węgla, a ściślej, wprowadzenia w ciągu 3 dekad gospodarki zeroemisyjnej, która wyśle do atmosfery tyle samo gazów cieplarnianych, ile w naturalny bądź wspomagany sposób będzie w stanie z niej usunaç ${ }^{53}$.

Od 2016 r. obserwuje się spadek udziału naszego kraju w wykorzystywaniu odnawialnych źródeł energii w ogólnym bilansie energetycznym. W ten sposób tworzy się w polskiej branży energetycznej technologiczny skansen. Tymczasem, jak wynika z obliczeń niemieckiego Instytutu Fraunhofera, trzeciej największej agencji badawczej na świecie, w 2018 r. najtańszym na niemieckim rynku źródłem energii były farmy fotowoltaiczne, następnie farmy wiatrowe, węgiel brunatny, panele fotowoltaiczne montowane na dachach domów. Najdroższy był prąd z węgla kamiennego i gazu. Należy jeszcze dodać, że nie uwzględniono energii atomowej ${ }^{54}$.

Zawęglenie polskiej energetyki jest faktem - elektrownia w Bełchatowie to największa na świecie siłownia węgla brunatnego. I tak właśnie w uzależnionej od tego surowca Polsce energetyka odpowiada tylko, albo aż, za około $30 \%$ emisji gazów cieplarnianych. Atmosferę niszczą również: rolnictwo, transport, budownictwo i budynki komunalne, które przecież trzeba ogrzewać. W sumie, w przeliczeniu na jednego mieszkańca, Polska emituje rocznie 8,3 tony dwutlenku węgla. To dużo. Gdyby jego emisję przeliczyć na każdy tysiąc dolarów wytworzonego PKB, otrzymamy wynik 0,3 tony. To o połowę więcej niż na Słowacji czy na Węgrzech, a podobnie jak w USA. I o połowę mniej niż w Chinach, największym trucicielu atmosfery, odpowiadającym za $27 \%$ emisji światowych (na Polskę przypada niecały procent) ${ }^{55}$.

Zdecydowana większość naszych krajowych elektrowni to zdekapitalizowane urządzenia $\mathrm{z}$ lat 70 ., a nawet 60 . XX w., które w najbliższych latach należy wyłączyć. Tak czy inaczej Polskę czeka znaczny wysiłek inwestycyjny, ponieważ

\footnotetext{
Tamże, s. 34.

Tamże.

R. Omachel, dz. cyt., s. 36.

Tamże, s. 38.

Tamże, s. 38-39.
} 
relegowane bloki energetyczne trzeba zastąpić nowymi źródłami. Problem w tym, że rząd nie do końca wie czym. Przewidywano, że elektrownia atomowa ma ruszyć w 2030 r., ale faktycznie, nikt już w tę datę nie wierzy. Część bloków mają zastąpić instalacje na gaz. Nawet turbiny wiatrowe, które zgodnie z Polityką Energetyczną Polski miały zniknąć z krajobrazu, powoli wracają do łask ${ }^{56}$.

W sektorze transportu rozwiązanie problemu emisji dwutlenku węgla wydaje się w dużej mierze formalnością. Wprawdzie na tę chwilę ustawa o elektromobilności nadal pozostaje głównie na papierze, polskiego samochodu elektrycznego nie ma nawet na deskach kreślarskich, ale prywatne firmy eksperymentują z autami dostawczymi i autobusami na prąd. Bardziej złożony problem stanowi transformacja przemysłu. Borykają się z tym prawie wszystkie kraje unijne. $\mathrm{O}$ ile huty, przynajmniej w teorii, można zasilić zewnętrznymi źródłami energii opartymi na technologiach bezemisyjnych, o tyle z cementowniami będzie to dość trudne. Przed potężnym wyzwaniem stoi również rolnictwo. Reasumując, jak wyliczyli eksperci WiseEuropa, koszt wprowadzenia w Polsce gospodarki zeroemisyjnej będzie przez kilka dekad kosztować do $1 \%$ PKB rocznie. W sumie koszty poszybują w górę w setki miliardów, może przekroczą bilion, co stanowi mniej więcej połowę dzisiejszego naszego PKB. A to przecież gigantyczne sumy. Pozostaje pytanie, czy możemy sobie pozwolić na to, żeby ich nie wydać? ${ }^{57}$.

Ciekawe stanowisko przedstawił prof. Marek Konarzewski, biolog z Uniwersytetu w Białymstoku, który twierdzi, że: „Ogromną redukcję zanieczyszczeń zawdzięczamy zmianom ekonomicznym, a nie trosce o środowisko. Bo jeśli chodzi o ochronę przyrody, wciąż jesteśmy w ogonie Europy. [...] Klimat się zmienia. I co do tego chyba już nikt nie ma wątpliwości. Zagrożenie jest widoczne także w Polsce, np. w połowie maja (2019 r. - J.B.T.) na Lubelszczyźnie przeszło sześć trąb powietrznych. Takie zjawiska dawniej zdarzały się znacznie rzadziej"58. Porównanie jakość powietrza w Warszawie, Krakowie czy Katowicach 40 lat temu a teraz, prowadzi do wniosku, że dziś oddychamy czystym powietrzem. Uzasadnienie tego jest stosunkowo proste - wówczas Nowa Huta, Huta Skawina pod Krakowem, Huta Katowice i inne zakłady przemysłu ciężkiego wyrzucały ogromne ilości pyłów. Trzy dekady temu branżę tę zlikwidowano, fabryki i huty pozamykano. Nie mamy także kwaśnych deszczy - importu gazów z dawnego NRD oraz Czechosłowacji, które doprowadziły do wymarcia całych połaci lasu w Górach Izerskich. Pozostaje zatem pytanie: skąd ten smog? Pochodzi on przede wszystkim z przydomowych kotłowni, przemysłu, transportu. Ale to nie jedyne problemy. Pod koniec kwietnia 2019 r. obserwowaliśmy w Polsce burze pyłowe, które pojawiły się w szerokim pasie na północ od Warszawy, przez Kujawy i dotarły prawie do Gdańska. Zjawisko to było związane z silnymi prądami powietrza, które przyszły do nas z Afryki. W Polsce mieliśmy wówczas suszę,

\footnotetext{
56 Tamże, s. 39.

57 Tamże.

58 D. Romanowska, Czy potrafimy się wyżywić, „Newsweek Polska” 2019, nr 23, s. 62.
} 
stąd wiatr zdmuchiwał z pół cząsteczki mineralne. Taka zawiesina pyłowa stanowi poważne zagrożenie dla zdrowia, znacznie większe niż zanieczyszczenia pochodzace z przemysłu i samochodów ${ }^{59}$.

$\mathrm{Na}$ koniec warto zauważyć, że kompletne przedstawienie sektora energetycznego III Rzeczypospolitej jest trudne z uwagi na fakt, że sytuacja na rynku jest dynamiczna, ulega częstym przemianom, a do ratyfikowanych umów dołączane są liczne aneksy. Kwestie związane z bezpieczeństwem energetycznym pokazują, jak zmieniła się polska polityka zagraniczna w XX i XXI wieku. Pytania o nasze bezpieczeństwo energetyczne, a rzadziej o kwestie ekologii, są tematami dyskusji i media chętnie spekulują o „wojnach o gaz” i zagładzie ekologicznej. Ten sektor gospodarki nadal wzbudza wiele kontrowersji i stanowi wyzwanie dla kolejnych rządów. Warto wspomnieć tutaj o ciekawym rozwiązaniu zaproponowanym przez Komisję Europejską - corocznie przyznaje ona nagrodę miastu (powyżej 100 tys. mieszkańców) wyróżniającemu się pod względem wzrostu gospodarczego, poprawy jakości życia mieszkańców i ochrony środowiska. Pomysł zrodził się w 2008 r., a pierwszą nagrodę (przyznaną w 2010 r.) zdobył Sztokholm ${ }^{60}$.

\section{Summary}

\section{Between Economics and Ecology. Energy Security of the Third Polish Republic}

Energy security is an extremely important area of every country's activity. The management of the energy sector affects immediate functioning of the entire economy, and further the state of the natural environment. After Poland's integration with the European Union, our country had to comply with the Community regulations. The constantly growing interdependence between states is an extremely important tendency of modern civilization. Oil and gas resources are declining, but the demand for these raw materials is not diminishing. It is estimated that there will be enough coal for some time, but burning all its resources would be a huge burden for the environment, because in this way global greenhouse gas emissions would increase even more.

Keywords: safety, energy safety, energy, fuels, natural gas, petroleum

59 Tamże, s. 62-63.

60 I. Brunner, Misja: brak emisji, „Forum” 2019, nr 14, s. 50-51. 


\section{Bibliografia}

\section{Opracowania}

Baca K., Czerwińska D., Tani węgiel? To już mit, „Rzeczpospolita” 2011, nr 22 (8838).

Bendyk E., Jak nie zginać i zarobić?, „Polityka” 2018, nr 44 (3184).

Bezpieczeństwo energetyczne. Nowy pomiar świata, pod red. A. Kretkowskiego, D. Szweda, Szczecin 2009.

Bezpieczeństwo energetyczne państwa, red. E. Ura, S. Pieprzny, Rzeszów 2015.

Bezpieczeństwo energetyczne wyzwaniem XXI wieku, red. Z. Lach, Warszawa 2013.

Bezpieczeństwo międzynarodowe. Teoria i praktyka, pod red. K. Żukrowskiej, M. Grącik, Warszawa 2006.

Białek J., Oleksiuk A., Gospodarka i geopolityka. Dokąd zmierza świat?, Warszawa 2009.

Breński W., Wybrane problemy gospodarki globalnej i ich wptyw na bezpieczeństwo międzynarodowe, [w:] Bezpieczeństwo międzynarodowe. Wyzwania i zagrożenia XXI wieku, red. P. Olszewski, T. Kapuśniak, W. Lizak, Radom 2009.

Brunner I., Misja: brak emisji, „Forum” 2019, nr 14 (5-18.07.2019).

Bryc A., Rosja w XXI wieku. Gracz światowy czy koniec gry?, Warszawa 2009.

Czarny R.M., Tomala, M., Wymiar pótnocny Unii Europejskiej. Studium rozwoju, Kielce 2009.

Ćwiek-Karpowiecz J., Bezpieczeństwo energetyczne Rosji, t. XII, Warszawa 2018.

Ćwieluch J., Skóra i ości, „Polityka” 2019, nr 29 (3219).

Ekonomiczne instrumenty ochrony środowiska. Emisje pod nadzorem, „Nowe Życie Gospodarcze" 2010, nr 12.

Foremny D., Bezpieczeństwo energetyczne, [w:] Bezpieczeństwo państwa. Wybrane problemy, red. K.A. Wojtaszczyk, A. Materska-Sosnowska, Warszawa 2009.

Forowicz K., Trudne lata dla polskich przedsiębiorców. Surowe limity darmowych uprawnień CO2, „Nowe Życie Gospodarcze” 2010, nr 12.

Gaz a sprawa polska, „Tygodnik Powszechny” 2009, nr 47 (3150).

Gołębiewski J., Anatomia bezpieczeństwa, Warszawa 2015.

Jartyś J., Stosunki polsko-niemieckie w aspekcie bezpieczeństwa europejskiego, [w:] Bezpiecznie czy niebezpiecznie? Wybrane aspekty globalnej i polskiej polityki bezpieczeństwa na przełomie XX i XXI wieku, pod red. J.J. Piątka, R. Podgórzańskiej, Szczecin 2007.

Karpiuk D., Już mamy katastrofe, ,Newsweek Polska” 2019, nr 29.

Kaźmierczak J., Bezpieczeństwo energetyczne-implikacje uzależnienia Polski od importu gazu ziemnego, Warszawa 2008.

Kochanek E., Geopolityka energetyczna współczesnych państw, Szczecin 2016.

Koziej S., Wyzwania transformacyjne bezpieczeństwa Polski, „Bellona” 2010, nr 2.

Kraciuk J., Jabłoński A., Bezpieczeństwo energetyczne Polski, [w:] Bezpieczeństwo międzynarodowe. Wyzwania i zagrożenia XXI wieku, pod red. P. Olszewskiego, T. Kapuśniaka, W. Lizaka, Radom 2009.

Kuźniar R., Droga do wolności. Polityka zagraniczna III Rzeczpospolitej, Warszawa 2008.

Łoskot A., Bezpieczeństwo dostaw rosyjskiego gazu do UE - kwestia połaczeń infrastrukturalnych, Warszawa 2005.

Mackiewicz A., Gaz a sprawa polska, „Tygodnik Powszechny”, 2009, nr 47.

Makowski A., Kubiak K., Znaczenie kierunku morskiego w dywersyfikacji dostaw gazu ziemnego a bezpieczeństwo surowcowe kraju, [w:] Współczesne wyzwania bezpieczeństwa europejskiego, pod red. P. Mickiewicz, K. Kubiak, Pelpin, Warszawa 2004.

Mayer B., Czas na małe, lokalne źródta energii, „Rzeczpospolita” 2011, nr 22 (8838).

Międzynarodowe bezpieczeństwo energetyczne w XXI wieku, pod red. E. Cziomera, Kraków 2008.

Młynarski T., Bezpieczeństwo energetyczne i ochrona klimatu w drugiej dekadzie XXI wieku. Energia - Środowisko - Klimat, Kraków 2017. 
Młynarski T., Polityka energetyczna Unii Europejskiej w pierwszej połowie drugiej dekady XXI wieku, [w:] Bezpieczeństwo energetyczne we wspótczesnych stosunkach międzynarodowych. Wyzwania, zagrożenia, perspektywy, red. M. Pietraś, J. Misiągiewicz, Lublin 2017.

Naimski A., Analiza wyniku polsko-rosyjskich negocjacji gazowych, „Międzynarodowy Przegląd Polityczny" 2010, nr 2/26.

Nowakowski Z., Polityka bezpieczeństwa energetycznego Polski. Wpływ europeizacji i globalizacji, Warszawa 2016.

Pietraś M., Autonomiczność bezpieczeństwa energetycznego w stosunkach międzynarodowych, [w:] Bezpieczeństwo energetyczne we współczesnych stosunkach międzynarodowych. Wyzwania, zagrożenia, perspektywy, red. M. Pietraś, J. Misiągiewicz, Lublin 2017.

Piński J., Pakt Putin-Schroeder, „Wprost” 2005, nr 37.

Ronek G., Polityka bezpieczeństwa energetycznego Rosji, [w:] Bezpieczeństwo energetyczne we wspótczesnych stosunkach międzynarodowych. Wyzwania, zagrożenia, perspektywy, red. M. Pietraś, J. Misiągiewicz, Lublin 2017.

Ruszel M., Bezpieczeństwo energetyczne Polski. Wymiar teoretyczny i praktyczny, Warszawa 2014.

Stańczyk J., Współczesne pojmowanie bezpieczeństwa, Warszawa 1996.

Szlagowski P., Priorytety polskiej polityki energetycznej w Trzecim Strategicznym Przegladzie Sytuacji Energetycznej, „Międzynarodowy Przegląd Polityczny” 2010, nr 2/26.

Włoch R., Bezpieczeństwo ekonomiczne państwa, [w:] Bezpieczeństwo państwa. Wybrane problemy, pod red. K.A. Wojtaszczyk, A. Materskiej-Sosnowskiej, Warszawa 2009.

Wybranowski D., Bezpieczeństwo Polski w stosunkach z Federacja Rosyjska w 2005 roku - zagrożenia i perspektywy, [w:] Bezpiecznie czy niebezpiecznie? Wybrane aspekty globalnej i polskiej polityki bezpieczeństwa na przełomie XX i XXI wieku, pod red. J.J. Piątka, R. Podgórzańskiej, Szczecin 2007.

Zając J., Bezpieczeństwo państwa, [w:] Bezpieczeństwo państwa. Wybrane problemy, pod red. K.A. Wojtaszczyk, A. Materskiej-Sosnowskiej, Warszawa 2009. 